\title{
MANAJEMEN RISIKO K3 MENGGUNAKAN HAZARD IDENTIFICATION RISK ASSESSMENT AND RISK CONTROL (HIRARC)
}

YOHANA PASARIBU

yohanapasaribu2@gmail.com

\section{Latar Belakang}

Peranan tempat layanan kesehatan masyarakat semakin meningkat seiring dengan perkembangan manusia dan kemajuan zaman. Sesuai peranannya sebagai tempat pelayanan kesehatan masyarakat umum, Rumah Sakit diharapkan berperan secara global erat kaitannya dengan manusia sebagai imdividu yang sangat membutuhkan pelayanan kesehatan khususnya di Rumah Sakit.

Rumah sakit merupakan institusi pelayanan kesehatan yang kompleks, padat profesi dan padat modal. Pelayanan rumah sakit menyangkut berbagai fungsi pelayanan, pendidikan, penelitian dan juga mencakup berbagai tindakan maupun disiplin medis. Rumah Sakit adalah tempat kerja yang memiliki potensi terhadap terjadinya kecelakaan kerja. Bahan mudah terbakar, gas medik, radiasi pengion, dan bahan kimia merupakan potensi bahaya yang memiliki risiko kecelakaan kerja. Oleh karena itu, Rumah Sakit membutuhkan perhatian khusus terhadap keselamatan dan kesehatan pasien, staf dan umum (Sadaghiani, 2001 dalam Omrani dkk., 2015).

Dari beberapa komponen pelayanan kesehatan Rumah Sakit ,perawat adalah salah satu tenaga pelayan kesehatan yang memiliki intensitas yang paling tinggi dalam berinteraksi dengan pasien dibandingkan dengan komponen yang lainnya. Hal tersebut membuat perawat selalu berhadapan langsung dengan bahaya dan dapat mengancam keselamatan dan kesehatan perawat itu sendiri maupun orang-orang yang ada disekitarnya. Oleh karena itu sangat penting adanya perhatian terhadap kesehatan dan keselamatan kerja bagi perawat.

Hal inilah yang melatarbelakangi penulis untuk melakukan penelitian mengenai . Manajemen Risiko K3 Menggunakan Hazard Identification Risk Assessment And Risk Control (HIRARC) Tujuan penelitian ini adalah untuk mengetahui Manajemen Risiko K3 Menggunakan Hazard Identification Risk Assessment And Risk Control (HIRARC) . 
Kata Kunci : manajemen risiko, k3,HIRARC,perawat METODE

Jurnal ini menggunakan metode literature review dari berbagai sumber seperti buku referensi jurnal, e-book, dan juga membandingkan beberapa jurnal yang berhubungan dengan Manajemen Risiko K3 Menggunakan Hazard Identification Risk Assessment And Risk Control (HIRARC). Dari analisi berbagai sumber yang digunakan untuk mengetahui Manajemen Risiko K3 Menggunakan Hazard Identification Risk Assessment And Risk Control (HIRARC). Pengolahan jurnal dilakukan dengan metode membandingkan beberapa jurnal yang berkaitan dengan Manajemen Risiko K3 Menggunakan Hazard Identification Risk Assessment And Risk Control (HIRARC) .

\section{HASIL}

Berdasarkan analisa dan eksplorasi serta kajian ebook dan jurnal ebook. Hasil penelitian di beberapa Negara membuktikan bahwa rumah sakit adalah salah satu tempat kerja yang berbahaya dan perawat adalah salah satu petugas kesehatan yang berisiko untuk mengalami gangguan kesehatan dan keselamatan kerja akibat dari pekerjaannya. Sebagai gambaran, biro statistik ketenagakerjaan dan Konsil Nasional Asuransi Amerika (2013) menyimpulkan pada rumah sakit di Amerika setiap 100 jam kerja terjadi 6,8 kejadian kecelakaan kerja dan penyakit akibat kerja (PAK). Angka ini menempatkan kecelakaan kerja dan PAK di rumah sakit sedikit lebih tinggi dibanding dengan kecelakaan kerja dan PAK di sector lainnya, seperti sektor konstruksi, manufaktur, dan pelayanan profesional dan bisnis lainnya. Sebanyak $48 \%$ kecelakaan kerja disebabkan karena penggunaan tenaga/otot yang berlebihan oleh perawat ketika menangani pasien, seperti mengangkat, memindahkan atau menjangkau pasien, dan peralatan medis lainnya. Selain itu, 54\% jenis kecelakaan yang dialami berhubungan dengan gangguan musculoskeletal, seperti sprain dan strain otot, dan hal ini menempatkan gangguan

muskuloskeletal sebagai penerima klaim kompensasi terbesar dari biaya rumah sakit. Kerugian material yang harus dikeluarkan dari kecelakaan kerja dan PAK setiap tahunnya sekitar 2 Milyar US\$.

Penelitian lainnya di negara berkembang seperti India juga menyimpulkan hasil yang sama. Sandeep, Shreemathi, Kalyan, Teddy, Kapil, dan Prachi (2016) melaporkan dalam 1 tahun terakhir 5,4\% perawat rumah sakit di India mengalami luka akibat tertusuk jarum suntik, 7,4\% mengalami varises, dan 56,9\% mengalami stres kerja. Situasi menegangkan yang sering dialami 
perawat adalah tindakan kekerasan dan pelecehan dari pasien. Sementara itu data-data tentang kecelakaan kerja dan penyakit akibat kerja pada petugas kesehatan rumah sakit di Indonesia belum tercatat dan dilaporkan dengan baik, hal ini mengindikasikan penerapan Kesehatan dan Keselamatan Kerja di rumah sakit di Indonesia masih memerlukan upaya perbaikan.

Maka dari itu perlu diketahui faktor -faktor yang membahayakan perawat tersebut dan usaha yang dapat dilakukan untuk meminimalkan risiko gangguan kesehatan dan keselamatan kerja dari aktivitas pekerjaan yang dilakukan perawat yaitu pengelolaan risiko atau dikenal dengan manajemen risiko. Menurut standar Australia/New Zealand (2004), pada dasarnya manajemen risiko bersifat pencegahan terhadap terjadinya kerugian maupun kecelakaan kerja. Langkah-langkah pengelolaan risiko dilakukan secara berurutan yang bertujuan untuk membantu dalam pengambilan keputusan yang lebih baik dengan melihat risiko dan dampak yang kemungkinan ditimbulkan. Tujuan dari manajemen risiko itu sendiri adalah meminimalkan kerugian dengan urutan terdiri dari Identifikasi Bahaya (Hazards Identification), Penilaian Risiko (Risk Assessment) dan Pengendalian Risiko (Risk Control) .

\section{PEMBAHASAN}

\section{IDENTIFIKASI BAHAYA}

\section{Pengertian}

Bahaya adalah sumber,situasi, atau tindakan yang berpotensi mencederai manusia atau sakit penyakit atau kombinasi dari semuanya (Puspitasari,2010). Berdasarkan Kurniawan (2008) mengatakan bahwa hazard adalah faktor faktor intrinsik yang melekat pada pada sesuatu berupa barang atau kondisi dan mempunyai potensi menimbulkan efek kesehatan maupun keselamatan pekerja serta lingkungan yang memberikan dampak buruk.

Terdapat 5 (lima) faktor bahaya K3 di tempat kerja ,antara lain:

1. Potensi bahaya fisika yang teridentifikasi yaitu pencahayaan, dengan melakukan perawatan terhadap pasien pada siang hari. Dapat terjadi resiko bahaya kelelahan mata, keluhan pegal dan efisiensi kerja menurun. Potensi bahaya kimia yang teridentifikasi yaitu disinfektan, dengan melakukan pembersihan ruangan. Dapat terjadi resiko bahaya keracunan, cedera mata dan infeksi. Dari Undang-undang No 1 Tahun 1970 tentang keselamatan kerja, BAB III Pasal 3 ayat 1 memelihara 
kebersihan, kesehatan dan ketertiban. Serta Permenkes No 66 Tahun 2016 tentang Keselamatan Dan Kesehatan Kerja Rumah Sakit BAB III Standar Keselamatan Dan Kesehatan Kerja,bahwa bahaya kimia yaitu disinfektan berada di semua area dan pekerja yang paling beresiko yaitu petugas kebersihan dan perawat.

2. Potensi bahaya biologi yang teridentifikasi yaitu melakukan perawatan pada penderita penyakit menular. Dapat terjadi resiko bahaya tertular penyakit AIDS, tertular tuberkulosis, tertular Hepatitis A dan Hepatitis B, tertular difteri. Dari Undangundang No 36 Tahun 2009 tentang Kesehatan BAB X penyakit menular dan tidak menular bagian kesatu penyakit menular pasal 152 ayat (2) upaya pencegahan, pengendalian, dan pemberantasan penyakit menular dilakukan untuk melindungi masyarakat dari tertularnya penyakit, menurunkan jumlah yang sakit, cacat dan/atau meninggal dunia, serta untuk mengurangi dampak sosial dan ekonomi akibat penyakit menular. Ayat (3) Upaya pencegahan, pengendalian, dan penanganan penyakit menular dilakukan melalui kegiatan promotif, preventif, kuratif, dan rehabilitatif bagi individu atau masyarakat. Ayat (4) Pengendalian sumber penyakit menular sebagaimana dimaksud pada ayat (3) dilakukan terhadap lingkungan dan/atau orang dan sumber penularan lainnya. Kepmenkes RI Nomer: 382/Menkes/SK/III/2007 tentang pedoman pencegahan dan pengendalian infeksi di Rumah Sakit dan fasilitas kesehatan lainnya, BAB II yang berisi fakta-fakta penting beberapa penyakit menular diantaranya HIV/AIDS dan Tuberkulosis.

3. Potensi bahaya ergonomi yang teridentifikasi yaitu melakukan restrain, memandikan pasien, dan mengganti pakaian pasien. Dapat terjadi resiko bahaya nyeri punggung, nyeri sendi, nyeri otot, dan luka memar dari postur tubuh yang salah melakukan pekerjaan berulang dan mendapat serangan dari pasien seperti terpukul dan tercakar. Dalam Undang-undang Nomor 23 Tahun 1992 tentang Kesehatan, pasal 23 mengenai kesehatan kerja disebutkan bahwa upaya kesehatan kerja wajib diselenggarakan pada setiap tempat kerja, khususnya tempat kerja yang mempunyai resiko bahaya kesehatan yang besar bagi pekerja agar dapat bekerja secara sehat tanpa membahayakan diri sendiri dan masyarakat sekelilingnya, untuk memperoleh produktivitas kerja yang optimal, sejalan dengan program perlindungan tenaga kerja. Serta Permenkes No 66 Tahun 2016 tentang keselamatan dan kesehatan kerja Rumah 
Sakit BAB III standar keselamatan dan kesehatan kerja bahwa potensi bahaya ergonomi yaitu postur tubuh yang salah dan melakukan pekerjaan yang berulang

4. Potensi bahaya psikososial yang teridentifikasi yaitu dinas malam yang melebihi 8 jam, mengani pasien halusinasi, menangani pasien yang defisit perawatan diri, melakukan terapi bermain/TAK. Dapat terjadi resiko stress, rasa takut berlebih, emosi, terpukul, tercakar, panik, mendapat serangan dan perilaku tidak baik dari pasien. Dari Undang-undang No. 1 Tahun 1970 tentang Keselamatan Kerja BAB III syarat-syarat keselamatan kerja pasal 3, dan Kepmenkes RI Nomor 432/MENKES/SK/IV/2007 tentang pedoman manajemen kesehatan dan keselamatan kerja (K3) di Rumah Sakit bahwa dalam kegiatan rumah sakit berpotensi menimbulkan bahaya fisik, kimia, biologi, ergonomi, dan psikososial, yang dapat membahayakan kesehatan dan keselamatan baik terhadap pekerja, pasien, pengunjung maupun masyarakat di rumah sakit.

\section{Penilaian Risiko}

Penilaian risiko merupakan salah satu proses dari analisis risiko, penilaian risiko dalam penelitian ini menggunakan metode kualitatif yaitu dengan matrik risiko yang menggambarkan tingkat dari kemungkinan dan keparahan suatu kejadian yang dinyatakan dalam bentuk rentang dari risiko paling rendah sampai risiko tertinggi.

1. Penilaian resiko melakukan perawatan terhadap pasien pada siang hari diketahui tingkat keparahan 1 dan tingkat kemungkinan A dengan resiko kategori High.

1) Keparahan 1 insignificant, tidak terjadi cedera dengan kerugian finansial kecildengan alasan dapat menimbulkan kelelahan dalam bekerja karena pencahayaan yang belum sesuai.

2) Kemungkinan A almost certain, dapat terjadi setiap saat dalam kondisi normal dengan alasan pekerjaan tersebut dilakukan setiap hari.

2. Penilaian resiko melakukan pembersihan ruangan diketahui tingkat keparahan 3 dan tingkat kemungkinan D dengan resiko kategori Moderate.

1) Keparahan 3 moderate, cedera sedang, perlu penanganan medis, kerugian finansial besar dengan alasan dapat terjadi keracunan ketika kontak dengan disinfektan dan terpeleset sehingga berisiko luka memar bahkan patah tulang. 
2) Kemungkinan $\mathrm{D}$ unlikely, kemungkinan jarang terjadi dengan alasan karena ketika ingin membersihkan ruangan pasien di amankan di ruangan dan memberi tanda ketika lantai sedang dibersihkan.

3. Penilaian resiko melakukan perawatan pada penderita penyakit menular diketahui tingkat keparahan 3 dan tingkat kemungkinan A dengan resiko kategori Extreme.

1) Keparahan 3 moderate, cedera sedang, perlu penanganan medis, kerugian finansial besar dengan alasan dapat tertular berbagai penyakit menular seperti HIV/AIDS, Hepatitis, tuberculosis, dan lainnya yang tentunya perlu pananganan medis untuk menyembuhkannya.

2) Kemungkinan A almost certain, dapat terjadi setiap saat dalam kondisi normal dengan alasan melakukan penanganan pasien dilakukan setiap hari dan ketika pasien gaduh dapat mengenai perawat/petugas dengan demikian petugas terpajan penyakit menular dari pasien.

4. Penilaian resiko diketahui untuk melakukan restrain tingkat keparahan 2 dan tingkat kemungkinan B dengan resiko kategori High.

1) Keparahan 2 minor, cedera ringan kerugian finansial sedang dengan alasan dapat menyebabkan nyeri sendi, nyeri punggung yang diakibatkan oleh postur tubuh yang salah.

2) Kemungkinan Blikely, kemungkinan terjadi sering dengan alasan ketika perawat melakukan pekerjaan tentu kontak dengan pasien sehingga pasien yang gaduh akan menyerang atau dengan tidak sengaja melukai perawat/petugas.

5. Untuk memandikan pasien tingkat keparahan 2 dan tingkat kemungkinan D dengan resiko kategori Low.

1) Keparahan 2 minor, cedera ringan kerugian finansial sedang dengan alasan alasan dapat menyebabkan nyeri sendi, nyeri punggung yang diakibatkan oleh postur tubuh yang salah.

2) Kemungkinan $\mathrm{D}$ unlikely, kemungkinan terjadi jarang dengan alasan tidak semua pasien dimandikan perawat, pasien biasanya dapat melakukan mandi sendiri namun tetap di awasi oleh perawat.

6. Untuk mengganti pakaian pasien tingkat keparahan 2 dan tingkat kemungkinan B dengan resiko kategori High. 
1) Keparahan 2 minor, cedera ringan kerugian finansial sedang dengan alasan dapat mengakibatkan nyeri otot, nyeri punggung, karena melakukan pekerjaan berulang dan luka memar atau gores karena mendapat serangan dari pasien.

2) Kemungkinan B likely, kemungkinan terjadi sering dengan alasan karena untuk menjaga kebersihan pasien sehingga pekerjaan tersebut cukup sering dilakukan.

7. Penilaian resiko diketahui untuk dinas malam yang melebihi 8 jam tingkat keparahan 2 dan tingkat kemungkinan A dengan resiko kategori High.

1) Keparahan 2 minor, cedera ringan kerugian finansial sedang, alasan dapat terjadi stres dan dapat mengganggu pekerjaan sehingga menimbulkan insiden.

2) Kemungkinan A almost certain, dapat terjadi setiap saat dalam kondisi normal dengan alasan perawat/petugas rumah sakit tentunya bekerja dengan shift, ada pagi siang dan malam.

8. Untuk menangai pasien halusinasi tingkat keparahan 2 dan tingkat kemungkinan A dengan resiko kategori High.

1) Keparahan 2 minor, cedera ringan, kerugian finansial sedang dengan alasan dapat menimbulkan rasa takut berlebih, stres yang disebabkan oleh sering kontak dengan pasien.

2) Kemungkinan A almost certain, dapat terjadi setiap saat dengan alasan karena orang gangguan jiwa tiba-tiba muncul halusinasi dan terjadi kapanpun.

9. Untuk menangani pasien yang defisit tinggi perawatan diri (melatih BAB dan BAK) tingkat keparahan 2 dan tingkat kemungkinan B dengan resiko kategori High.

1) Keparahan 2 minor, cedera ringan, kerugian finansial sedang dengan alasan perawat/petugas dapat diserang tiba-tiba oleh pasien dan mendapat perilaku tidak baik seperti pasien melempar kotoran pada petugas.

2) Kemungkinan B likely, kemungkinan terjadi sering dengan alasan karena pekerjaan tersebut terjadi setiap saat kapanpun.

10. Untuk melakukan terapi bermain/TAK tingkat keparahan 2 dan tingkat kemungkinan B dengan resiko kategori High.

1) Keparahan 2 minor, cedera ringan, kerugian finansial sedang dengan alasan dapat terjadi luka memar dan lecet diakibatkan oleh terpukul atau diserang tiba-tiba oleh pasien. 
2) Kemungkinan Blikely, kemungkinan terjadi sering dengan alasan setiap hari selalu ada kegiatan melakukan terapi bermain/ TAK.

\section{Pengendalian Risiko}

Menurut Hanafi \& Partawibawa (2016), pengendalian resiko terhadap bahaya yang teridentifikasi dilakukan setelah dilakukan penilaian sebelumnya, sehingga pengendalian resiko bahaya diprioritaskan pada bahaya dengan kategori paling tinggi ke rendah. Pengendalian resiko pada kategori High dapat dilakukan dengan mengurangi resiko bahaya serendah mungkin sehingga resiko bahaya dapat diterima.

Upaya pengendalian bahaya fisika (pencahayaan) yaitu aktivitas kerja melakukan perawatan terhadap pasien pada siang hari adalah memperoleh penerangan yang cukup dan sesuai. Untuk pengendalian resiko yaitu gunakan pencahayaan yang baik agar penglihatan bisa melihat dengan jelas pada objek, untuk menghindari kemungkinan terjadinya penyakit akibat kerja dan kecelakaan akibat kerja.

Upaya pengendalian bahaya Kimia (disinfektan) yaitu aktivitas kerja melakukan perawatan terhadap pasien pada siang hari adalah harus memperhatikan tanda-tanda peringatan yang ada di area kerja untuk mengantisipasi adanya bahaya pada bahan kimia yang tersedia diruangan tersebut dan perhatikan penggunaan bahan kimia sesuai prosedur.

Upaya pengendalian bahaya biologi (tertular penyakit AIDS, Hepatitis A, Hepatitis B, Tuberkulosis) yaitu aktivitas kerja melakukan perawatan pada penderita penyakit menular adalah mengunakan APD yang dibutuhkan sesuai dengan pekerjaan, seperti menggunakan sarung tangan dan masker ketika kontak langsung dengan pasien diagnosa penyakit menular maupun tidak menular.

Upaya pengendalian bahaya ergonomi yaitu aktivitas kerja melakukan restrain, memandikan pasien, dan mengganti pakaian pasien adalah memahami SOP/SPO dalam melakukan pekerjaan. Melakukan cara kerja yang baik dalam SOP ergonimi yang baik dan benar, penerapan ergonomi yang tidak sesuai dengan sikap dan cara kerja dapat mengakibatkan lemah fisik dan nyeri sendi pada tubuh. Dan pekerjaan yang dilakukan berulang-ulang bisa menguras 
tenaga sehigga lebih dikurangi dengan mendesain ulang pekerjaan seperti menambah petugas/perawat untuk melakukan pekerjaan tersebut.

Upaya pengendalian bahaya psikososial adalah menghindari rasa takut pada pekerjaan yang membuat psikologi terganggu pada saat bekerja sehingga mengakibatkan penyakit akibat kerja dan kecelakaan kerja. Melakukan manajemen kerja dengan melakukan pelatihan untuk menangani pasien gangguan jiwa sehingga dapat mengetahui cara penanganan yang baik dan benar ketika pasien tiba-tiba akan menyerang atau gaduh gelisah.

\section{PENUTUP}

\section{KESIMPULAN}

Terdapat 5 (lima) faktor bahaya K3 di tempat kerja ,antara lain: faktor bahaya fisika, faktor bahaya biologi, faktor bahaya ergonomic, faktor bahaya psikososial.Penilaian risiko merupakan salah satu proses dari analisis risiko, penilaian risiko dalam penelitian ini menggunakan metode kualitatif yaitu dengan matrik risiko yang menggambarkan tingkat dari kemungkinan dan keparahan suatu kejadian yang dinyatakan dalam bentuk rentang dari risiko paling rendah sampai risiko tertinggi. Upaya pengendalian risiko dapat dilakukan dengan lima hirarki pengendalian risiko yaitu eliminasi, substitusi, teknik, administrasi, dan alat pelindung $\operatorname{diri}(\mathrm{APD})$.

\section{SARAN}

Hasil penelitian ini dapat dijadikan tambahan pengetahuan di bidang pendidikan dan dapat meningkatkan manajeman K3 bagi tenaga medis di Rumah Sakit terkhususnya perawat.

\section{DAFTAR PUSTAKA}

Djatnika, K, M., Arso, S, P., \& Jati, S, P. (2019). Analisis Pelaksanaan Manajemen Risiko di Instalasi Farmasi Rumah Sakit Umum Daerah Tugurejo Semarang Tahun 2018. JURNAL KESEHATAN MASYARAKAT, 7(1), 84-92.

Hidayah, W, S. (2019). Analisis Faktor Risiko dan Hazard Dalam Implementasi Keperawatan. ( Skripsi FIK Universitas Muhammadiyah Purwokerto). 
Indragiri, S. (2018). Manajemen Risiko K3 Menggunakan Hazard Identification Risk Assessement and Risk Control (HIRARC). JURNAL KESEHATAN, 9(1), 39-52.

Kardina, W, I., Abidin, A, U., \& Nurmiyanto, A. (2018). Manajemen Risiko Keselamatan dan Kesehatan Kerja (K3) di Rumah Sakit Jiwa Grhasia D.I. YOGYAKARTA, (https://dspace.uii.ac.id/bitstream/handle/123456789/10119/08\%20NASKAH\%20PUBLIKASI.p df?sequence $=17 \&$ is Allowed $=\mathrm{y}$ )

Kurniati, D. (2019). Manajemen Resiko Kesehatan dan Keselamatan Kerja Asuhan Keperawatan di IGD, (https://osf.io/yps4x/download/?format=pdf )

Putri, O, Z., Hussin, T, M, A, B, R., \& Kasjono, H, S. (2017). Analisis Risiko Keselamtan dan Kesehatan Kerja Pada Petugas Kesehatan InstaIasi Gawat Darurat Rumah Sakit Akademik UGM. JURNAL KESEHATAN, 10(1), 1-12.

Ramdan, I, M., \& Rahman, A. (2017). Analisis Risiko Kesehatan dan Keselamatan Kerja (K3) pada Perawat. JKP, 5(3), 229-241.

Ramadhan, F. (2017). Analisis Kesehatan dan Keselamatan Kerja (K3) Menggunakan Metode Hazard Identification Risk Assessment and Risk Control (HIRARC). Seminar Nasional Riset Terapan 2017, 164-169.

Simamora, R. H. (2011). ROLE CONFLICT OF NURSE RELATIONSHIP WITH PERFORMANCE IN THE EMERGENCY UNIT OF HOSPITALS RSD DR. SOEBANDI JEMBER. The Malaysian Journal of Nursing, 3(2), 23-32.

Sugian, S. (2006). Kamus Manajemen (Mutu). Jakarta: PT Gramedia Pustaka Utama.

Wardhani, V. (2017). Buku Ajar-Manajemen Keselamatan Pasien. Malang: UB Press. 